\title{
PERANAN WILĀYAT AL-MAZ̄̄ALIM DAN RELEVANSINYA DENGAN PENYELESAIAN KASUS PELANGGARAN HAK ASASI MANUSIA DI INDONESIA
}

\author{
Ikhwan \\ Universitas Islam Negeri Imam Bonjol Padang, Indonesia \\ E-mail: ikhwanjambak@gmail.com
}

\begin{abstract}
This article discusses the institution and the aplication of human rights court in Islamic court system based on data revealed from the books of hadith, sirah nabawiyah, history, Islamic law, and others. From a comparative analysis it can be concluded that the institution of wilayat al-mazălim can be seen as human rights court in Islam due to the similarity with the jurisdiction of Indonesian human rights court. If the authority of Indonesian human rights court is limited, that of wilayat al-mazalim is much wider as to cover the duties and authorities of other state bodies like the Commission of Truth and Reconciliation, State Administration Court, and the Commission of Ombudsman. Various regulation and practices of human rights in Islamic court as played by wilāyat al-mazălim can be used as positive input for building the institution of human rights court.
\end{abstract}

Keywords: Wilāyat al-mazălim; human rights violation; human rights court.

\section{Pendahuluan}

Pengadilan hak asasi manusia mulai mulai diwacanakan dan diimplementasikan semenjak berakhir Perang Dunia II, yakni ketika Pengadilan Meliter Internasional (International Military Tribunal) didirikan di Nuremberg oleh negara-negara sekutu pemenang Perang Dunia II untuk mengadili berbagai pelanggaran hak asasi manusia yang dilakukan Nazi Jerman, seperti genosida, pemusnahan etnis, pemerkosaan massal, dan lainnya. Para pemimpin Nazi didakwa telah melakukan kejahatan perang (war crime), kejahatan terhadap kemanusiaan (crimes against bumanity), dan kejahatan terhadap perdamaian (crimes against peace). Mahkamah yang sama juga didirikan di Tokyo untuk mengadili pelanggaran HAM yang dilakukan oleh 
para pemimpin Jepang dalam Perang Dunia II. ${ }^{1}$ Pada tahun 1993, PBB membentuk Pengadilan International (International Tribunal) untuk mengadili orang-orang yang bertanggung jawab atas kejahatan terhadap kemanusiaan dan pelanggaran hukum kebiasaan perang selama konflik di bekas Yugoslavia sejak tahun $1991 .^{2}$ Pada tahun 1994, PBB membentuk pula pengadilan internasional untuk mengadili kasus genosida dan pelanggaran serius terhadap Hukum Humaniter Internasinal di dalam wilayah Rwanda dan tetangganya. ${ }^{3}$ Pembentukan pengadilan hak asasi manusia $\mathrm{PBB}$ sempat pula diwacanakan pascajejak pendapat di Timor Timur. Pelbagai pihak menduga kuat sudah terjadi ragam pelanggaran hak asasi manusia yang serius di wilayah tersebut. Keinginan tersebut mengendur setelah pemerintah Republik Indonesia membentuk Pengadilan HAM Ad Hoc berdasarkan Undang-Undang Nomor 26 Tahun 2000 tentang Pengadilan Hak Asasi Manusia berikut peraturan pelaksanaannya.

Bila ditelusuri lebih mendalam, eksistensi pengadilan hak asasi manusia sesunguhnya memiliki akar sejarah yang panjang. Beberapa tradisi budaya dan sistem hukum, seperti Romawi, Persia, Arab, dan Islam, semenjak zaman dahulu tercatat telah mempunyai aturan dan lembaga yang menjalankan peran sebagai pengadilan hak asasi manusia. Kekayaan tradisi budaya dan sistem hukum yang ada tersebut perlu dipelajari dan diteliti sehingga dapat dimanfaatkan untuk pengembangan lembaga pengadilan hak asasi manusia pada masa sekarang dan yang akan datang.

Dalam konteks lembaga pengadilan hak asasi manusia ini, di dalam khasanah Islam, dikenal lembaga yang bernama wilayat almaz̧ălim. Lembaga ini dilihat dari kedudukan dan fungsinya memainkan peranan dalam penyelesaian kasus-kasus yang terkategori sebagai pelanggaran hak asasi manusia. Kertas kerja ini mencoba menjelaskan kedudukan dan peranan wilāyat al-mazăalim dan relevansinya dengan penyelesaian kasus-kasus pelanggaran hak asasi manusia serta perbandingannya dengan lembaga-lembaga terkait yang

\footnotetext{
1 Abdul Hakim Garuda Nusantara, "Mengadili Kasus-Kasus Pelanggaran Hak Asasi Manusia: Pengalaman Beberapa Negara", Makalah pada Seminar Nasional Rancangan Undang-Undang tentang Pengadilan Hak Asasi Manusia 16 Februari 2000, Jakarta: Direktorat Jenderal Hukum dan Perundang-undangan Departemen Hukum dan Perundang-undangan R.I.

2 Statute of the International Tibunal for Former Yugoslavia, Adopted 25 May 1993 as Amended 13 May 1998.

${ }^{3}$ Statute of the International Tibunal for Rwanda, 1994.
} 
ada dewasa ini. Analisis riset ini bersifat deskriptif-analitis. Data primer seputar wilāyat al-maz̧ălim dan peranannya dalam penyelesaian kasus pelanggaran hak asasi manusia dieksplorasi melalui studi kepustakaan terhadap kitab-kitab hadis, sirah nabawiyah, sejarah, fiqh dan lainnya. Data sekunder diperoleh dari bahan kepustakaan yang terkait dengan masalah yang dibahas. Data yang diperoleh diklasifikasi, dianalisis, dan disusun sesuai kerangka pembahasan untuk memperoleh gambaran mengenai kedudukan dan peranan wilāyat al-mazăalim dalam penyelesaian kasus pelanggaran hak asasi manusia. Konsep dan pelaksanaan tersebut kemudian dikomparasikan dengan pengadilan hak asasi manusia yang ada di Indonesia. Kesimpulan ditarik secara induktif.

\section{Eksistensi dan Peranan Wilāyat al-Mazālim}

Istilah wilāyat al-mazălim terbentuk dari kata wilāyah dan mazālim. Kata wilayyah antara lain bermakna kekuasaan dan pemerintahan. Sementara mazălim, jamak dari maz̧limah, berarti tindakan aniaya atau ketidakadilan. Jika dikaitkan dengan tindakan penguasa terhadap rakyat, maz̧limah berarti kesewanangan dan kezaliman dalam bertindak. Sedangkan jika dikaitkan dengan masalah hak, mą̧limah bermakna mengurangi hak. ${ }^{4}$ Jadi secara etimologis wilàyat al-mazălim berarti kekuasaan peradilan yang berwenang menyelesaikan perkara kezaliman penguasa terhadap rakyat.

Secara terminologis, para pakar peradilan Islam memberikan defenisi yang hampir senada dengan pengertian kebahasaan di atas. Muhammad 'Abd al-Raḥmān al-Bakr mendefinisikan wilāyat al-mažălim sebagai kekuasaan peradilan tertinggi yang berwenang mengadili perkara maz̧ălim yang terjadi antara anggota masyarakat dan aparat pemerintah di dalam suatu negara, di mana peradilan biasa tidak sanggup atau tidak berwenang mengadilinya. ${ }^{5}$ Wilāyat al-mazălim sengaja dibentuk khusus untuk membela orang-orang teraniaya (maz̧lim) akibat kesemena-menaan tindakan penguasa atau keluarganya yang biasanya sulit diselesaikan oleh pengadilan biasa (wilàyat al-qad̄à) dan kekuasaan hisbah (wilāyat al-hisbah), termasuk

\footnotetext{
${ }^{4}$ Louis Ma'lūf, al-Munjid fì al-Lughah (Beirut: al-Matba'ah al-Kāthūlikīyah, t.th.), 500.


al-Niz̄àm al-Islāmì (Kairo: Madīnah Naṣr, 1998), 524.
} 
menyelesaikan perkara penyuapan dan korupsi. ${ }^{6}$ Penyebutan keluarga pejabat negara sebagai pihak yang mungkin melakukan kezaliman didasari anggapan dan kenyataan bahwa mereka sering terlibat menggunakan pengaruh atau fasilitas yang diperoleh akibat kedekatan personal dengan pejabat negara.

Umumnya para pakar sepakat bahwa wilayat al-maz̧älim merupakan jenis peradilan yang muncul kemudian dalam sejarah perkembangan peradilan Islam. Ia berfungsi sebagai lembaga peradilan khusus di samping wilayat al-qadà sebagai lembaga peradilan umum. Namun terdapat perbedaan pendapat mengenai kapan awal terbentuk atau terselenggaranya wilāyat al-mazālim, apakah lembaga ini telah ada pada masa Nabi Muhammad atau belum. Sebagian sejarawan peradilan Islam berpendapat wilayat al-mazălim telah ada dan berjalan pada masa Nabi Muhammad, seperti dikemukakan al-Māwardī dengan mengutip kasus sengketa pengairan antara Zubayr b. al-Awwām, sepupu Nabi Muhammad, dan seorang laki-laki kaum Anșār. ${ }^{7}$ Penyelesaian kasus ini oleh Nabi Muhammad, menurut al-Māwardī, menggambarkan bahwa wilàyat al-mazălim telah terbentuk pada masa Nabi Muhammad. ${ }^{8}$

Sementara itu, sebagian ahli yang lain tidak sependapat jika wilayat al-maāalim telah terbentuk pada masa Nabi Muhammad karena tidak ditemukan titik pijak sejarah yang kuat. Menurut Muhammad Mahdī Shams al-Dīn, secara teoretis keberadaan wilāyat al-mazălim dibutuhkan

\footnotetext{
${ }^{6}$ Satria Effendi M. Zein, "Arbitrase dalam Syariat Islam", dalam Arbitrase Islam di Indonesia (Jakarta: Badan Arbitrase Muamalat Indonesia, 1994), 6.

${ }^{7}$ Kasus Zubayr termaktub dalam hadīth dari 'Abd Allāh b. Yūsuf, dari al-Layth yang berkata bahwa Ibn Shihāb meriwayatkan kepadanya dari 'Urwah, dari 'Abd Allah b. Zubayr bahwa sesungguhnya seorang dari golongan Anșār berperkara dengan Zubayr di hadapan Rasulullah mengenai aliran air (irigasi) di Harrah. Orang Anșār tersebut berkata: Alirkanlah air itu!" Zubayr menolak. Mereka lalu membawa sengketa itu ke hadapan Rasulullah. Kemudian Rasulullah bersabda: "Pakailah air itu hai Zubayr, lalu alirkan ke tetanggamu! Orang Anșār tersebut berkata: "Mentangmentang Zubayr itu anak bibimu". Wajah Rasulullah kemudian berubah warna mendengar ucapan tersebut. Lalu beliau bersabda kepada Zubayr sekali lagi: "Pakailah air itu hai Zubayr, lalu tahan air itu hingga menyusut dalam jumlah yang pantas!" Zubayr berkata: Saya menduga ayat ini (Maka demi Tuhanmu, mereka belumlah beriman sehingga mereka menjadikan kamu hakim terhadap perkara yang mereka perselisihkan) turun berkenaan dengan peristiwa tersebut. Lihat Abū 'Abd Allah Muḥammad b. Ismāīl b. Ibrāhīm b. al-Mughīrah b. Bardizbah al-Ju'fī alBukhārī, Șaḥị̣ al- Bukhārì, Vol. 6 (Beirut: Dār Ibn Kathīr, 1987), 832.

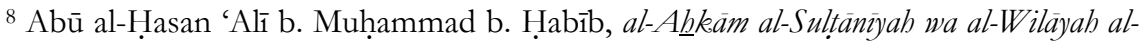
Dinìah (Beirūt: Dār al-Fikr, 1960), 77.
} 
pada situasi di mana telah banyak orang-terutama penguasa dan kerabatnya-melakukan kezaliman. Sementara aparat penegak hukum (termasuk peradilan atau al-qadä) tidak berdaya menghadapinya sehingga menimbulkan keresahan sosial. Kondisi dan prasyarat demikian jelas tidak terjadi pada masa Nabi Muhammad sebab tidak ditemukan bukti-buktinya di dalam sirah, hadīth, maupun sejarah. ${ }^{9}$ Hakikatnya kasus Zubayr bukan kasus mazälim, karena ia sebagai pelaku, bukan pejabat negara dan bukan pula tergolong kerabat dekat pejabat negara. Padahal salah satu ciri kasus maāalim adalah pelakunya penguasa atau kerabat dekatnya. ${ }^{10}$

Muhammad 'Abd al-Raḥmān al-Bakr berusaha memperkuat pendapat telah adanya pengadilan mazălim pada masa Nabi Muhammad. Banyak kasus yang dapat dikategorikan sebagai kasus mažălim terjadi pada masa Nabi Muhammad dan terekam di dalam kitab hadīth dan al-sirah al-nabawiyah. Misalnya, Nabi Muhammad pernah memecat al-'Ala' b. al-Hadramī, pejabat yang bertugas di Bahrain, setelah Nabi menerima informasi yang akurat dari 'Abd alQayth tentang deviasi yang dilakukan al-'Ala'. Sebagai gantinya, Nabi mengangkat Abban b. Sa'īd. Pada suatu riwayat dijelaskan juga bahwa Khālid b. Walīd telah membunuh anggota Kabilah Jadhīmah, padahal mereka telah menyatakan tunduk kepada kekuasaan Islam. Untuk mengyelesaikan kasus ini, Nabi mengutus 'Alī b. Abī Ṭālib untuk menyelidikinya dan mengadilinya. 'Alī kemudian memutuskan pembayaran diat atas pembunuhan yang dilakukan Khālid tersebut. Setelah membayar diat, Nabi berdoa: "Ya Allah, aku berlepas diri dari apa yang telah diperbuat Khālid". ${ }^{11}$

Dari berbagai keterangan yang dikemukakan oleh para pakar di atas, dapat disimpulkan bahwa pada dasarnya kasus-kasus mazālim telah mulai terjadi pada masa Nabi, meskipun jumlahnya masih sangat sedikit dan tidak bersifat meluas. Hal ini mungkin disebabkan oleh kualitas keimanan dan pengamalan agama umat Islam yang masih sangat baik ketika itu. Di samping itu, Nabi selalu memberikan bimbingan dan menanamkan nilai-nilai agar penguasa tidak bertindak zalim atau semena-mena. Namun, belum bisa dikatakan bahwa

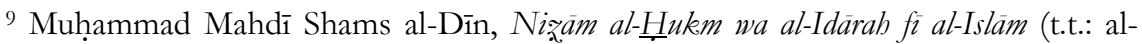
Mu'assasah al-Dawlīyah li al-Dirāsat wa al-Nashr, 1991), 559.

${ }^{10}$ Nāsir b. 'Āqil b. Jābir Ṭārifí, al-Qaḍā' fì 'Ahd 'Umar (Jeddah: Dār al-Madānī, 1986), 564.

11 al-Bakr, al-Sultah al-Qadä'zyah, 526. 
lembaga wilayat al-mazaalim telah dibentuk dan berjalan dengan baik. Paling bisa dikatakan bahwa cikal-bakal wilāyat al-maz̧ālim telah mulai tumbuh pada masa Nabi, sedangkan perangkat organisasinya belum terbentuk secara sempurna.

Pada masa al-Khulafā' al-Rāshidūn, lembaga wilāyat al-mazălim mulai berkembang dan dijalankan dengan relatif baik. 'Umar b. alKhattāāb tercatat sebagai khalifah yang paling berjasa membangun institusi dan praktik pengadilan atas kasus-kasus maz̧älim. Ibn al-Jawzī menceritakan bahwa 'Amr b. al-'Āsh berkata kepada seorang laki-laki Muslim di Mesir: "Hai munafik!" Laki-laki itu menjawab: "Aku tidak pernah berbuat kemunafikan semenjak masuk Islam! Aku bersumpah tidak akan membasuh kepalaku sehingga menemui 'Umar". Lelaki itu menemui 'Umar dan berkata: "Sesungguhnya 'Amr b. al-'Āsh menyebut aku seorang munafik. Padahal, demi Allah, aku tidak pernah berbuat kemunafikan sejak masuk Islam'. 'Umar menulis surat kepada 'Amr dengan nada marah: "Kepada al-'Āṣì (pelaku maksiat) b. al-'Āṣ. 'Ammā ba'd, sesungguhnya fulan mengatakan bahwa kamu memunafikkannya dan aku memerintahkan dia untuk mendatangkan dua orang saksi dan mencambukmu empat puluh kali". Setelah kembali ke Mesir dan bertemu di majelis 'Amr b. al-'Āsh, lelaki itu berdiri dan berkata: "Aku mohon kepada Allah, hendaklah berdiri laki-laki yang mendengar 'Amr b. al-'Āsh memunafikkan aku". Maka berdirilah sebagian besar orang yang sedang berada di masjid. Pengawal "Amr berkata: "Apakah kamu akan mencambuk Amir?" Lelaki itu kemudian ditawari uang sogokan, tetapi dia menolak. Pengawal itu berkata lagi: "Apakah anda tetap akan mencambuk Amir?" Lelaki itu menjawab: "Aku tidak melihat di sini 'Umar ditaati." "Amr b. al-"Ạṣ lalu berkata: "Biarkan dia memberikan cambukan." "Amr lalu duduk di hadapan lelaki tersebut. Lelaki itu bertanya: "Apakah kekuasaan anda dapat menghalangi aku?" "Amr menjawab: "Tidak, lakukanlah apa yang diperintahkan, aku pasrah kepada Allah". 'Umar juga pernah memberikan hukuman kepada Muhammad, anak 'Amr b. al-'Āṣ, yang melakukan kezaliman kepada seorang warga Mesir dengan memanfaatkan dan membanggakan kekuasaan dan kedudukan ayahnya. ${ }^{13}$

12 Muhammad Abū Zahrah, al-Jarimah wa al-Uqübah fì al-Fiqh al-Jinà̃ al-Islàmì (Kairo: Dār al-Fikr al-'Arabī, t.th.), 110-111.

13 'Abbās Mạ̄mūd al-'Aqqād, 'Abqarìyah 'Umar (Kairo: Manshurāt al-Maktabah al'Așrīyah, 1941), 118. 
'Umar berupaya keras menciptakan suasana keterbukaan di tengah masyarakat dalam rangka meminimalisir dan menghapuskan tindakan zalim para penguasa kepada rakyat. Rakyat diberi kesempatan yang luas untuk menyampaikan tindakan penyelewengan para penguasa. Ibadah haji dijadikan ajang sidang umum (jam'ìyah 'umümiyah) untuk menyiaran informasi dan kebijakan pemerintah ke seluruh jemaah yang datang dari segenap penjuru wilayah. Musim haji juga dimanfaatkan untuk melakukan konsolidasi dan evaluasi pelaksanaan pengeloaan negara dan tugas umum pemerintahan dengan para pejabat daerah, termasuk dengan petugas mazălim dan para pencari keadilan tentang pelaksanaan tugas dan kendala yang mereka hadapi. 'Umar juga mengadakan evaluasi dan konsolidasi dengan petugas pengawas untuk mengontrol kinerja kepala daerah dan pegawai pemerintah. $^{14}$

Pada masa Khalifah 'Alī b. Abī TTālib, eksistensi dan peranan wilayat al-mazălim semakin terasa sejalan dengan keadaan masyarakat yang tengah mengalami dekadensi moral dan degradasi pengamalan nilai-nilai agama. Berbagai tindakan pidana, kezaliman, dan ketidakadilan terjadi sebagai imbas dari penurunan kualitas akhlaq dan pertentangan politik, aliran, dan kelompok yang terjadi di tengah masyarakat. 'Alī menghadapi gejala negatif tersebut dengan tegas dan keras. Menurut al-Māwardī, 'Alī adalah orang pertama yang menggunakan kekuatan politik untuk menyelesaikan tindak pidana yang diadukan masyarakat. Meskipun demikian, 'Alī kelihatannya belum mendirikan lembaga khusus untuk menyelesaikan kasus mazălim, karena cara dan kebijakan yang ditempuhnya dipandang telah mampu menyelesaikan ragam kasus yang diajukan kepadanya. ${ }^{15}$

\section{Kewenangan Wilāyat al-Mazālim}

Al-Māwardī mengemukakan sepuluh kewenangan umum wilàyat al-mazăalim. Pertama, menyelesaikan kasus kezaliman penguasa terhadap rakyat dan segala bentuk penyimpangan kekuasaan yang mereka lakukan. Kedua, memeriksa kecurangan aparat pemerintah dalam pengelolaan dan administrasi dana negara (zakat, pajak, dan lain-lain). Ketiga, memeriksa hasil kerja pejabat pencatat dokumen negara dan meneliti kemungkinan terjadinya penambahan, pengurangan, dan

\footnotetext{
${ }^{14}$ Ibid., 106.

15 'Alī Muhammad b. Ḥabīb al-Māwardī, al-Aḅkām al-Sultānīyah wa al-Wilāyāt alDinìyah (Beirut: Dār al-Kutub al-'Ilmīyah, t.th.), 78.
} 
perubahan yang tidak jujur pada dokumen tersebut. Keempat, memeriksa kasus kezaliman terhadap pegawai negeri, seperti pembatalan, pengurangan, dan penundaan gaji, serta menetapkan sistem dan jumlah gaji yang adil. Kelima, mengembalikan harta dan hak rakyat yang diambil tanpa hak oleh penguasa atau orang kuat. Keenam, memeriksa pengelolaan dan persengketaan harta wakaf. Ketujuh, menangani dan mengeksekusi keputusan hakim pada tingkat peradilan biasa (wilāyat al-qad̄à) yang tidak mampu dilaksanakan karena kedudukan dan pengaruh terdakwa. Kedelapan, menangani kepentingan umum yang tidak mampu ditangani oleh wiläyat al-hisbah karena lemahnya mubtasib atau kuatnya kedudukan dan pengaruh pelaku pelanggaran. Kesembilan, mengawasi pelaksanaan ibadah-ibadah umum seperti salat jum'at, salat 'id, haji, jihad, dan lainnya. Kesepuluh, memeriksa kasus-kasus mað̧hälim lainnya, memutuskan hukumnya, dan melaksanakannya dengan adil. ${ }^{16}$

Di samping sepuluh kewenangan umum tersebut di atas, wilayat almazaălim masih memiliki beberapa kewenangan khusus, seperti mengupayakan penyelesaian perkara melalui perdamaian (al-shullb) di antara para pihak. Menurut 'Abd al-Qadim Zallum, wilāyat al-mazălim berwenang memutuskan apapun bentuk kezaliman, baik menyangkut aparat negara, penyimpangan yang dilakukan khalifah terhadap hukum syara', penafsiran konstitusi atau undang-undang, masalah pajak, dan lain-lain. Qạdì al-maz̧ālim juga berwenang memberikan sanksi hukum, seperti memberhentikan pejabat pemerintah, pegawai negeri, bahkan khalifah sendiri. ${ }^{17}$

Kekuasaan dan kewenangan yang dimiliki wilāyat al-mazăälim sangat besar dan meliputi ruang lingkup yang luas, melebihi apa yang dimiliki oleh lembaga peradilan lainnya. Sejalan dengan hal tersebut, kekuasaan dan kewenangan yang dimiliki oleh hakim wilàyat al-mazălim juga melebihi hakim-hakim lainnya. Ada beberapa kelebihan yang dimiliki oleh hakim wilāyat al-mazaalim yang tidak dimiliki hakim-hakim lainnya. Pertama, hakim wilāyat al-maz̧ălim memiliki otoritas yang lebih kuat untuk mencegah permusuhan dan kezaliman. Kedua, ruang lingkup kerjanya lebih luas. Ketiga, memiliki kekuasaan menggunakan berbagai cara untuk mengungkapkan kebenaran dan kebatilan. Keempat, berwenang memberikan tindakan yang bersifat pendidikan

${ }^{16}$ Ibid., 80-83.

17 Abdul al-Qadim Zallum, Sistem Pemerintahan Islam, terj. Moh. Maghfur Wachid (Bangil: al-Izzah, 2002), 249-250. 
(ta'dīb) terhadap orang yang terbukti melakukan kezaliman. Kelima, berwenang menunda penetapan putusan hukum jika terdapat ketidakjelasan pada kasus yang dihadapi. Keenam, berwenang mencegah atau mengakhiri permusuhan melalui mekanisme perdamaian (al-sulh) atas keinginan dan kerelaan para pihak. Ketujuh, berwenang menetapkan kewajiban-kewajiban tertentu kepada para pihak yang bermusuhan, seperti jaminan, jika terdapat indikasi penyelewengan dan kebohongan hingga mereka berlaku benar dan adil. Kedelapan, berwenang memanggil para saksi dan meminta kesaksian mereka tentang fakta-fakta sekira perselisihan yang terjadi. Kesembilan, berwenang menerima kesaksian orang yang tidak dikenal, tetapi adil. Kesepuluh, berwenang memerintahkan para saksi agar bersumpah jika diragukan kesaksian mereka. ${ }^{18}$

Untuk menjalankan tugas-tugas yang besar dan berat tersebut, ditambah lagi dengan kewenangan khusus sebagaimana dipaparkan di atas, dibutuhkan para hakim yang berkualitas agar tugas yang diemban dapat dijalankan dengan baik. Oleh karena itu, seorang hakim ( qä dì almazăälim) yang bertugas di peradilan wilāyat al-mazălim mesti memenuhi kriteria dan kualifikasi tertentu untuk menjamin kualitas dan kinerja peradilan. Al-Nabhānī menyebutkan di samping diharuskan memenuhi syarat-syarat umum sebagai hakim, seperti Muslim, merdeka, baligh, berakal, dan ahli fiqh yang bisa memahami hukum dan aplikasinya, seorang hakim pada wilāyat al-maz̧älim juga diharuskan memenuhi syarat-syarat khusus, yakni laki-laki dan mujtahid. Disyaratkan seorang laki-laki karena hakim maz̧ălim bertugas memutuskan dan menerapkan hukum, termasuk kepada para penguasa, sehingga diperlukan sifat-sifat yang umumnya dimiliki lakilaki. Sedangkan kapasitas mujtahid diperlukan karena hakim mazălim kemungkinan akan menemukan kasus penguasa yang menerapkan hukum selain dari hukum Allah atau menerapkan hukum yang tidak berlandaskan dalil shara ${ }^{6}$ atau menggunakan dalil yang tidak cocok. ${ }^{19}$

Kualifikasi dan kriteria yang lebih lengkap tentang hakim wilayat al-maāălim dikemukakan oleh al-Māwardī. Menurut al-Mawardi, seorang hakim pada wilāyat al-mazaălim mesti memiliki kualitas dan karakter yang menggabungkan ketegasan aparat keamanan dan

18 al-Māwardī, al-Ạ̣kēm al-Sultānìyah, 80-83; Shawkat 'Ilyān, Qaḍà' al-Mažālim fì alIslām (Baghdād: Maṭba'at al-Jāmi'ah, 1977), 115-116.

19 Taqiyuddin Nabhani, Sistem Pemerintahan Islam: Doktrin, Sejarah, dan Realitas Empirik (Bangil: al-Izzah, 1996), 251. 
ketegaran hakim. Oleh karena itu, seorang hakim wilāyat al-mazălim harus memiliki syarat-syarat yang dibutuhkan untuk itu. Pertama, jalil al-qadr, yakni memiliki pengaruh atau kekuasaan yang besar dan kedudukan yang mulia di mata masyarakat; Kedua, näfidh al-amr, perintah dan keputusannya dipatuhi; Ketiga, 'ażim al-haybah, yakni memiliki wibawa yang tinggi; Keempat, sāahir al-iffah, yang bermakna dikenal sebagai orang yang bersih dan menjaga diri; Kelima, qalì altham i, tidak bersifat rakus dan ambisius; dan keenam, kathir al-wara', memiliki sikap warak yang tinggi. ${ }^{20}$

Pengaruh yang besar dan kedudukan yang mulia diperlukan bagi seorang hakim wilayat al-mazălim karena pihak yang akan diadili adalah orang-orang yang memiliki kekuasaan dan pengaruh. Dengan pengaruh dan kedudukan yang dimilikinya, hakim wilāyat al-mazălim tidak akan merasa takut, minder, atau segan untuk menyelesaikan perkara dan menerapkan hukum secara adil. Hakim wilāyat al-mazaălim mesti orang yang perintahnya didengar dan dipatuhi agar semua keputusan yang ditetapkannya dalam rangka penyelesaian perkara dapat dipatuhi dan dijalankan (dieksekusi) dengan baik.

Wibawa yang tinggi diperlukan agar timbul rasa segan dan hormat para pihak terhadap pribadi dan keputusan yang diambil hakim wilayat al-mazălim sehingga semua keputusan dipatuhi dan dilaksanakan dengan baik. Tanpa wibawa yang tinggi bisa saja terjadi pelecehan terhadap pribadi dan keputusan yang diambil hakim oleh para pihak yang berperkara. Sifat bersih dalam makna terhindar dari segala bentuk penyelewengan, kecurangan, dan pelanggaran hukum sangat dibutuhkan bagi seorang hakim wilāyat al-mazălim untuk memperkuat kredibilitas dan memperkokoh legitimasi. Pada perkara-perkara besar yang ditangani, sangat mungkin terjadi praktik sogok, iming-iming jabatan, dan rayuan lain dari pihak-pihak yang berkepentingan. Oleh sebab itu, hakim wilāyat al-mazălim harus terhindar dari sifat rakus dan ambisius agar bisa menghadapi berbagai rayuan dan cobaan tersebut. Sedangkan sikap wara' diperlukan agar hakim wilāyat al-mazălim betulbetul menjaga kehormatan dan kesucian diri, menghindari hal-hal

\footnotetext{
${ }^{20}$ Dilihat dari kualifikasi hakim dan kewenangan yang dimilikinya, lembaga wilāyat almaz̧ālim memiliki fungsi juga sebagai peradilan koneksitas, yakni pengadilan yang menyelesaikan perkara tindak pidana yang dilakukan bersama-sama oleh orangorang yang termasuk lingkungan Peradilan Umum dan lingkungan Peradilan Militer. Lihat: Kitab Undang-Undang Nomor 8 Tahun 1981 tentang Hukum Acara Pidana (KUHAP) Pasal 89-94. al-Māwardī, al-A Ạkēm al-Sultānìyah, 77.
} 
yang merusak nama baik pribadi dan menjatuhkan kredibiltas lembaga, serta benar-benar memperjuangkan kebenaran dan keadilan.

\section{Pelanggaran Hak Asasi Manusia dan Pengadilan Hak Asasi Manusia di Indonesia}

Pelanggaran hak asasi manusia per defenisi memiliki kriteria dan batasan tertentu. Pasal 1 angka 6 Undang-Undang Nomor 39 Tahun 1999 tentang Hak Asasi Manusia memuat defenisi yang cukup baik tentang pelanggaran hak asasi manusia, yaitu: "Setiap perbuatan seorang atau sekelompok orang termasuk aparat negara, baik disengaja maupun tidak disengaja atau kelalaian, yang secara melawan hukum mengurangi, menghalangi, membatasi, dan atau mencabut hak asasi manusia seorang atau sekelompok orang yang dijamin oleh undang-undang ini dan tidak mendapatkan atau dikhawatirkan tidak akan memperoleh penyelesaian hukum yang adil dan benar berdasarkan mekanisme hukum yang berlaku".

Ruang lingkup perbuatan yang merugikan hak asasi manusia tersebut diatur lebih lanjut di dalam bab III pasal 9-66 UndangUndang Nomor 39 Tahun 1999 yang meliputi hak hidup, hak berkeluarga dan melanjutkan keturunan, hak mengembangkan diri, hak memperoleh keadilan, hak atas kebebasan pribadi, hak atas rasa aman, hak atas kesejahteraan, hak turut serta dalam pemerintahan, hak-hak wanita, dan hak-hak anak. Defenisi di atas juga menyebutkan bahwa subyek pelaku pelanggaran hak asasi manusia dapat berupa orang seorang dan dapat pula berupa sekelompok orang yang secara bersama-sama melakukan suatu pelanggaran hak asasi manusia. Penambahan kata-kata "...termasuk aparat negara...." merupakan suatu penekanan dan perhatian khusus karena secara faktual, pelanggaran hak asasi manusia banyak dilakukan oleh aparat negara. Penekanan ini merupakan salah satu ciri khas kasus pelanggaran hak asasi manusia. Nuansa khusus ini oleh para ahli disebut sebagai salah satu bentuk khusus dari kejahatan politik (political crimes). Kejahatan politik dapat dibedakan kepada kejahatan melawan penguasa dan kejahatan yang dilakukan penguasa. Kejahatan melawan penguasa (crimes against the government) adalah seperti pemberontakan, demonstrasi ilegal, terorisme, gerakan subversif. Sedangkan kejahatan yang dilakukan oleh penguasa (crimes by government, state crimes, political policing, governmental crimes) adalah seperti pelanggaran hukum oleh aparat pemerintah, militer, intelijen. Pelanggaran hak asasi manusia termasuk 
ke dalam kategori kedua dari kejahatan politik. Pelanggaran hak asasi manusia mempunyai nuansa khusus, yakni penyalahgunaan kekuasaan dalam arti pelaku berbuat dalam konteks pemerintahan dan difasilitasi oleh kekuasaan pemerintah (committed within a govermental context and facilitated by governmental power). Bahkan dikatakan juga bahwa perbuatan melanggar hak asasi manusia dilakukan dalam kerangka atau disertai asosiasi dengan status pemerintahan (within or in association with governmental status). ${ }^{21}$ Pada kenyataannya, pelanggaran hak asasi manusia umumnya dilakukan oleh aparat negara, terutama militer.

Penggalan terakhir dari defenisi di atas, yakni: ...dan tidak mendapatkan atau dikhawatirkan tidak akan memperoleh penyelesaian bukum yang adil dan benar berdasarkan mekanisme bukum yang berlaku merupakan ciri khas lain dari pelanggaran hak asasi manusia. Kekhawatiran ini bisa disebabkan oleh kelemahan peraturan perundang-undangan dan bisa juga karena pengaruh pelaku pelanggaran hak asasi manusia. Sebagaimana disinyalir, aparat negara adalah pihak yang paling berpeluang dan paling sering melakukan pelanggaran HAM, sementara mereka memiliki kekuasaan yang dapat diselewengkan untuk mempengaruhi proses dan hasil persidangan.

Karena sifatnya yang khas, pelanggaran hak asasi manusia, terutama yang berat, memerlukan penanganan khusus dan berbeda dibanding dengan pelanggaran hukum pada umumnya. Di Indonesia, penyelesaian kasus pelanggaran hak asasi manusia diserahkan kepada suatu pengadilan khusus yang bernaung di bawah peradilan umum yang disebut dengan pengadilan hak asasi manusia. Pasal 104 ayat (1) Undang-Undang Nomor 39 Tahun 1999 tentang Hak Asasi Manusia mengatur bahwa untuk mengadili pelanggaran hak asasi manusia yang berat, dibentuk pengadilan hak asasi manusia di lingkungan peradilan

21 Muladi, Prospek Pengaturan Pengadilan Hak Asasi Manusia (HAM) di Indonesia, Makalah pada Seminar Nasional Rancangan Undang-Undang Pengadilan HAM, Jakarta, 16 Februari 2000, Diselenggarakan oleh Direktorat Jenderal Hukum dan Perundang-Undangan Departemen Hukum dan Perundang-undangan R.I., hal. 7. Pembagian tindak pidana politik kepada kejahatan melawan negara/penguasa dan kejahatan oleh penguasa merupakan perkembangan baru dalam hukum pidana. Pada pembagian hukum pidana secara konvensional, pembagian seperti itu tidak ditemukan. Tindak pidana politik hanya diarahkan kepada kejahatan melawan negara/pemerintah yang sah. Lihat antara lain EY. Kanter dan S.R. Sianturi, Asasasas Hukum Pidana di Indonesia dan Penerapannya (Jakarta: Storia Grafika, 2002), 240, Andi Hamzah, Asas-asas Hukum Pidana (Jakarta: PT. Rineka Cipta, 1994), 102 dan Wirjono Prodjodikoro, Asas-asas Hukum Pidana di Indonesia (Bandung: Eresco, 1989), 6. 
umum. Term pelanggaran hak asasi manusia yang berat sengaja dipakai untuk menunjukkan kualitas dan tingkat keseriusan pelanggaran hak asasi manusia, di samping untuk memberikan batasan yang jelas bagi jurisdiksi pengadilan hak asasi manusia. Penjelasan pasal 104 ayat (1) menerangkan bahwa yang dimaksud dengan pelanggaran hak asasi manusia yang berat adalah kejahatan-kejahatan yang tergolong kepada pembunuhan massal (genocide), pembunuhan sewenang-wenang atau di luar putusan pengadilan (arbitrary/extra judicial killing), penyiksaan, penghilangan orang secara paksa, perbudakan, atau diskriminasi yang dilakukan secara sistematis (systematic discrimination).

Pasal 4 Undang-Undang Nomor 26 tahun 2000 tentang Pengadilan Hak Asasi Manusia kembali menegaskan bahwa pengadilan hak asasi manusia hanya bertugas dan berwenang memeriksa dan memutus perkara pelanggaran hak asasi manusia yang berat. Ruang lingkup dan rincian pelanggaran hak asasi manusia yang berat dimuat pada pasal 7-9 dimana kategorisasinya disederhanakan menjadi dua macam, yaitu kejahatan genosida (genocide) dan kejahatan terhadap kemanusiaan (crimes againts bumanity).

Pengadilan Hak Asasi Manusia merupakan pengadilan khusus yang berada di lingkungan Peradilan Umum sehingga kompetensi relatifnya mengikuti ketentuan yang berlaku di Peradilan Umum. Kompetensi relatif Pengadilan Hak Asasi Manusia diatur dalam pasal pasal 3 Undang-Undang Nomor 26 Tahun 2000 yang menyatakan bahwa Pengadilan Hak Asasi Manusia berkedudukan di daerah kabupaten atau kota yang daerah hukumnya meliputi daerah hukum Pengadilan Negeri yang bersangkutan. Untuk DKI Jakarta, pengadilan hak asasi manusia berkedudukan di setiap wilayah pengadilan negeri yang bersangkutan. ${ }^{22}$

22 Untuk pertama kali, menurut ketentuan pasal 45 Undang-Undang Nomor 26 Tahun 2000, Pengadilan Hak Asasi Manusia dibentuk di Jakarta Pusat, Surabaya, Medan, dan Makassar. Daerah hukum Pengadilan Hak Asasi Manusia Jakarta Pusat meliputi wilayah Daerah Khusus Ibukota Jakarta, Provinsi Jawa Barat, Banten, Sumatera Selatan, Lampung, Bengkulu, Kalimantan Barat, dan Kalimantan Tengah. Daerah hukum Pengadilan Hak Asasi Manusia Surabaya meliputi Provinsi Jawa Timur, Jawa Tengah, Daerah Istimewa Yogyakarta, Bali, Kalimantan Selatan, Kalimantan Timur, Nusa Tenggara Barat, dan Nusa Tenggara Timur. Daerah hukum Pengadilan Hak Asasi Manusia Makassar meliputi Provinsi Sulawesi Selatan, Sulawesi Tenggara, Sulawesi Tengah, Sulawesi Utara, Maluku, Maluku Utara, dan Irian Jaya. Daerah hukum Pengadilan Hak Asasi Manusia Medan meliputi Provinsi Sumatera Utara, Daerah Istimewa Aceh, Riau, Jambi, dan Sumatera Barat. 
Pasal 5 Undang-Undang Pengadilan Hak Asasi Manusia mengatur bahwa Pengadilan Hak Asasi Manusia juga berwenang untuk memeriksa dan memutus perkara pelanggaran hak asasi manusia yang berat yang dilakukan di luar batas teritorial wilayah negara Republik Indonesia oleh warga negara Indonesia. Ketentuan ini bertujuan untuk melindungi warga negara Indonesia yang melakukan pelanggaran hak asasi manusia yang berat yang dilakukan di luar batas teritorial, dalam arti tetap dihukum sesuai dengan Undang-Undang Pengadilan Hak Asasi Manusia, bukan berdasarkan peraturan perundang-undangan negara lain. Sementara itu, pasal 6 UndangUndang Pengadilan Hak Asasi Manusia mengatur bahwa kewenangan Pengadilan Hak Asasi Manusia dibatasi menyangkut umur pelaku pelanggaran hak asasi manusia, dimana pengadilan hak asasi manusia tidak berwenang memeriksa dan memutus perkara pelanggaran hak asasi manusia yang berat yang dilakukan oleh seseorang yang berumur di bawah 18 (delapan belas) tahun pada saat kejahatan dilakukan. Jika pelaku pelanggaran hak asasi manusia yang berat berumur di bawah 18 (delapan belas) tahun, maka kasusnya diperiksa dan diputus oleh Pengadilan Negeri.

\section{Wilāyat al-Mazālim dan Penyelesaian Kasus Pelanggaran HAM}

Dari ruang lingkup yurisdiksi dan bukti-bukti empiris dalam sejarah panjang wilayyat al-mazălim terlihat jelas bahwa peranan institusi ini sangat erat kaitannya dengan upaya penegakan hak asasi manusia dan penyelesaian kasus pelanggaran hak asasi manusia sehingga bisa dipersamakan dengan lembaga dan kewenangan pengadilan hak asasi manusia pada saat ini. Sebagaimana dijelaskan sebelumnya, menurut ketentuan peraturan perundang-undangan Indonesia dan Statuta Roma tentang Pengadilan HAM Internasional, pelanggaran HAM adalah perbuatan yang memenuhi kriteria-kriteria: 1) melanggar hak asasi manusia; 2) dilakukan oleh-biasanya — aparat negara (crimes by government, state crimes, political policing, governmental crimes); 3) dikhawatirkan tidak memperoleh penyelesaian hukum yang adil dan benar jika melalui peradilan biasa; dan 4) ditujukan kepada penduduk sipil sebagai suatu serangan meluas atau sistematik. Aspek dan titik persamaanya dapat dijelaskan sebagai berikut.

Pertama, titik fokus yurisdiksi wilāyat al-maz̧älim adalah mengadili perkara kezaliman atau kesewangan tindakan terhadap rakyat sipil yang secara substantif dikategorikan dan memenuhi syarat sebagai 
pelanggaran hak asasi manusia. Dengan demikian, kriteria pertama dari tindak pidana pelanggaran hak asasi manusia, yakni adanya tindak pelanggaran terhadap hak asasi manusia, ditemui di dalam perkaraperkara yang menjadi ruang lingkup yurisdiksi wilāyat al-maz̧ălim. Dengan kata lain, wilāyat al-maz̧ălim memiliki kewenangan mengadili kasus-kasus pelanggaran hak asasi manusia.

Kedua, secara khusus wilāyat al-mazălim berwenang mengadili kasus kezaliman penguasa terhadap rakyatnya, termasuk kezaliman yang dilakukan keluarga pejabat dan orang-orang memiliki pengaruh kuat di tengah masyarakat. Sifat perkara yang menjadi kewenangan wilāyat al-maāălim ini identik dengan kriteria kedua tindak pidana pelanggaran hak asasi manusia, yakni terlibatnya penguasa atau orang yang berpengaruh sebagai pelaku pada kebanyakan tindak pelanggaran hak asasi manusia.

Ketiga, kelahiran institusi wilayyat al-mażälim ditujukan untuk mengadili kasus-kasus kezaliman yang sulit atau tidak mampu diselesaikan secara baik dan adil oleh pengadilan biasa (wilāyat al-qad̄a) dan kekuasaan hisbah (wilayat al-hisbah) karena kedudukan dan pengaruh yang dimiliki pelakunya. Wilayat al-mazaălim diberikan tugas dan wewenang khusus untuk menyelesaikan kasus-kasus semacam itu karena jika diberikan kepada pengadilan lain dikhawatirkan tidak dapat diselesaikan secara adil dan benar. Fungsi dan kewenangan khusus wilayat al-mazălim ini sesuai dengan salah satu kriteria tindak pidana pelanggaran hak asasi manusia pada peraturan perundang-undangan Indonesia, yakni setiap perbuatan melanggar hak asasi manusia yang dijamin oleb undang-undang dan tidak mendapatkan atau dikhawatirkan tidak akan memperoleh penyelesaian bukum yang adil dan benar berdasarkan mekanisme bukum yang berlaku. (Pasal 1 angka 6 Undang-Undang Nomor 39 Tahun 1999 tentang Hak Asasi Manusia).

Adapun kriteria keempat dari karakteristik tindak pidana pelanggaran hak asasi manusia yang tidak sepenuhnya ditemukan secara eksplisit di dalam defenisi dan batasan kewenangan wilàyat almazălim, yakni ditujukan kepada penduduk sipil dan bersifat sistematis dan meluas. Dari segi sasaran, tindakan al-mazaălim juga ditujukan kepada penduduk sipil, yakni warga negara. Sedangkan sifat meluas dan sistematis lebih tergantung kepada keadaan kasus per kasus secara individual. Dalam kenyataannya, wilàyat al-mazălim dalam peradilan Islam pernah mengadili kasus pelanggaran hak asasi manusia yang bersifat sistematis dan meluas tersebut, seperti kasus Khālid b. Walīd. 
Dengan demikian dapat disimpulkan bahwa terdapat banyak kesamaan antara yurisdiksi wilayat al-maz̧älim pada sistem peradilan Islam dan tindak pelanggaran hak asasi manusia, termasuk pelanggaran hak asasi manusia berat yang merupakan yurisdiksi dari Pengadilan Hak Asasi Manusia yang ada saat ini. Hal ini sekaligus menunjukkan bahwa wilāat al-mazălim memiliki kedudukan yang penting dan peranan yang besar di dalam upaya perlindungan hak asasi manusia dan penyelesaian kasus-kasus pelanggaran hak asasi manusia di dalam sistem peradilan Islam.

Peranan lebih luas dari wilayyat al-mazaälim dalam rangka penegakan hak asasi manusia dan penyelesaian perkara-perkara pelanggaran hak asasi manusia dapat dilihat juga dari kewenangan umum yang dimiliki wilāyat al-mazălim. Dari sepuluh kewenangan umum yang dimiliki oleh wilayat al-mazălim, terdapat beberapa jurisdiksi yang terkait erat dengan penegakan hak asasi manusia.

Pertama, wilàjat al-maz̧ălim berwenang menyelesaikan perkara pelanggaran hukum yang dilakukan penguasa terhadap rakyat dan segala bentuk penyimpangan yang mereka perbuat selama berkuasa, meneliti sikap dan tingkah laku para pejabat dan keluarganya, mencegah mereka melakukan pelanggaran dan ketidakjujuran, dan berwenang juga memecat dan mengganti para pejabat yang tidak adil dan tidak jujur. Di samping berwenang secara khusus mengadili perkara kezaliman penguasa dan keluarganya, wilāyat al-mazălim juga berwenang memeriksa dan mengadili kasus-kasus perselisihan dan persengketaan yang terjadi di tengah masyarakat untuk kemudian memutuskan hukumnya dan melaksanakan keputusan hukum tersebut dengan adil.

Kedua, wilayat al-mazaălim berwenang memeriksa dan melakukan investigasi jika terdapat indikasi kecurangan aparat pemerintah dalam pemungutan dan administrasi dana negara (zakat, pajak, dan lain-lain). Dalam hal terbukti adanya kecurangan di dalam pemungutan yang menzalimi rakyat, wilāyat al-mazălim bertugas dan berwenang mengembalikan harta pungutan liar dan korupsi kepada pemiliknya, baik harta itu telah disetorkan oleh aparat kepada kas negara ataupun diambil untuk kepentingan dirinya sendiri.

Ketiga, wilàyat al-maz̧älim berwenang memeriksa dan menyelesaikan perkara kezaliman terhadap pegawai negeri, seperti tindakan-tindakan pembatalan, pengurangan, dan penundaan gaji. Untuk menghindari terjadinya tindakan yang merugikan para pegawai negeri tersebut, 
wilāyat al-mazălim berwenang menyusun dan menetapkan sistem penggajian dan jumlah gaji yang adil bagi para pegawai.

Keempat, wilàyat al-mazaălim bertugas dan berwenang mengembalikan hak-hak rakyat yang disita atau dirampas secara tanpa hak, baik oleh aparat pemerintah maupun orang-orang kuat di dalam masyarakat. Kewenangan seperti ini pernah dipraktikkan secara baik dan tegas pada masa Khalifah 'Umar b. 'Abd al-'Azīz di mana ia mengembalikan semua harta rakyat (maz̧limah) yang dirampas penguasa Bani Umayyah sebelumnya. Ia juga menyita tanah-tanah dan harta milik negara yang dijadikan milik pribadi oleh penguasa dan aparat negara sebelumnya. ${ }^{23}$

Kelima, wilayat al-maz̧ălim berwenang menangani perkara-perkara yang tidak dapat diselesaikan oleh peradilan biasa (wilāyah al-qadhä) dan peradilan hisbah (wilāyah al-bisbah) dan juga berwenang mengeksekusi keputusan hakim yang dikeluarkan oleh kedua lembaga peradilan tersebut. Hal ini biasanya terjadi karena pelaku perkara kezaliman adalah orang yang memiliki kedudukan dan pengaruh yang kuat. Wilāyat al-maz̧ălim diberikan tugas semacam ini karena ia memiliki otoritas yang lebih kuat dan kewenangan yang lebih luas. Sumber daya yang dimiliki lebih mumpuni untuk melaksanakannya sebab hakim (qādì al-mazălim atau nāąir al-mazălim) pada wilāyat almazăäim merupakan orang-orang yang memiliki kedudukan yang tinggi dan terhormat di mata masyarakat, perintahnya dipatuhi, beribawa, bersih, wara', tidak rakus dan tidak ambisius. ${ }^{24}$

Di samping kewenangan tersebut di atas, wilayat al-maz̧älim juga berwenang mengarahkan para pihak yang berperkara untuk mengakhiri sengketa dengan perdamaian (al-sulb) atas dasar keinginan dan keridhaan para pihak. ${ }^{25}$ Dengan demikian, kewenangan yang dimiliki wilāyat al-mazaalim bukan hanya menyelesaikan perkara melalui mekanisme biasa di pengadilan, tetapi juga dengan mekanisme penyelesaian di luar pengadilan, seperti perdamaian. Hal ini memang telah dilaksanakan sejak masa awal perkembangan peradilan Islam sebagaimana terjadi pada kasus Khālid b. Wālid dan lainnya.

\footnotetext{
${ }^{23}$ al-Māwardī, al-Aḥkāom al-Sultānìyah, 78.

${ }^{24}$ Ibid., 77.

25 'Ilyān, Qaḍā’ al-Mažălim, 115-116.
} 


\section{Penutup}

Wilāyat al-mazălim memiliki peranan yang sangat penting di dalam upaya penegakan dan perlindungan hak asasi manusia, di mana posisi ini berperan besar dalam penyelesaian kasus pelanggaran hak asasi manusia, khususnya kasus kezaliman penguasa dan kerabatnya terhadap rakyat. Jika konsep Pengadilan Hak Asasi Manusia seperti di Indonesia diproyeksikan kepada pembagian peradilan yang ada pada sistem peradilan Islam, dapat dikatakan bahwa pada kadar dan tingkatan tertentu wilayat al-mazălim menempati posisi dan menjalankan peranan Pengadilan Hak Asasi Manusia. Di samping itu, wilāyat al-mazālim juga berwenang menyelesaikan perkara pelanggaran hak asasi manusia melalui mekanisme rekonsiliasi (ishläh/sulh) yang dewasa ini dijalankan oleh lembaga lain, yakni Komisi Kebenaran dan Rekonsiliasi (KKR). Meskipun demikian, mesti pula dipahami bahwa lembaga-lembaga tersebut jelas memiliki perbedaan-perbedaan mengingat perbedaan latar belakang, setting sejarah, sistem dan format peradilan, fungsi, tugas, dan kewenangan masing-masing.

Selain memiliki banyak kesamaan dengan Pengadilan Hak Asasi Manusia dan Komisi Kebenaran dan Rekonsiliasi, wilāyat al-mazălim dalam batasan tertentu juga memiliki kesamaan dengan lembagalembaga lain yang banyak berperan dalam penegakan hak asasi manusia. Dilihat dari segi fungsinya sebagai lembaga pengawas pelaksanaan pemerintahan, wilayyat al-mazălim, pada tingkat dan kadar tertentu memiliki kesamaan dengan Komisi Ombudsman. ${ }^{26}$ Komisi Ombudsman bertugas mengawasi performa pemerintahan agar tidak terjadi penyalahgunaan kekuasaan dan ketidakadilan sehingga aparatur negara terdorong melaksanakan pemerintahan secara efisien, adil, dan bertanggungjawab. Lembaga ini dibutuhkan untuk membangun demokrasi, akuntabilitas, transparansi, menjunjung tinggi hak asasi manusia, memberantas mala-administrasi, korupsi, kolusi, dan nepotisme, baik di kalangan aparatur pemerintahan, birokrasi,

26 Komisi Ombudsman berdiri pertama kali di Swedia tahun 1809, kemudian berkembang menjadi beberapa lembaga, seperti the Parliamentary Ombudsman, Freedom of Commerce Ombudsman, Consumer Ombudsman, dan Press Ombudsman. Saat ini, lebih dari seratus negara telah memiliki lembaga semacam Ombudsman, termasuk Indonesia yang dibentuk melalui Keputusan Presiden No.44 Tahun 1999. Lima puluh negara mencantumkan tentang Ombudsman di dalam konstutusi mereka. Lihat: Swedish Institute, Fact Sheets on Sweden (Sweden, January 1972) dan Antonius Sujata, "Ombudsman dalam Konstitusi”, Forum Keadilan, No. 27, (7 Oktober 2001), 23. 
maupun peradilan aparat pemerintah senantiasa memperhatikan asasasas pemerintahan yang baik (good governance), supremasi hukum, dan kesantunan. Wilāyat al-mazălim juga memiliki kesamaan dengan Pengadilan Tata Usaha Negara dari segi tugas dan wewenangnya menangani sengketa antara badan atau pejabat tata usaha negara dan orang atau badan hukum menyangkut keputusan tata usaha negara yang menimbulkan kerugian, sehingga hak-hak warga negara terjamin dan terlindungi dari segala bentuk pelanggaran dan kezaliman sehingga terwujud kehidupan masyarakat madani berdasarkan prinsip kebenaran, keadilan, dan supremasi hukum. ${ }^{27}$

Dengan demikian dapat dikatakan bahwa yurisdiksi wilayyat almazălim dan Pengadilan Hak Asasi Manusia Indonesia memiliki banyak kesamaan. Bedanya, kewenangan yang dimiliki wilayyat almaāalim lebih luas sehingga mencakup tugas dan kewenangan lembaga-lembaga lain yang ada dewasa ini, seperti Komisi Kebenaran dan Rekonsiliasi (KKR), Pengadilan Tata Usaha Negara (PTUN), dan Komisi Ombudsman. Berbagai aturan dan praktik pengadilan hak asasi manusia pada peradilan Islam seperti yang diperankan oleh wilāyat al-mazălim dapat dijadikan masukan positif bagi pembangunan institusi Pengadilan HAM. Demikian juga dengan lembaga-lembaga lain yang terkait dengan penegakan dan perlindungan hak asasi manusia, seperti lembaga Ombudsman dan Peradilan Tata Usaha Negara.

\section{Daftar Rujukan}

'Aqqād (al), 'Abbās Mah̄mūd. 'Abqarìyah 'Umar. Kairo: Manshurāt alMaktabah al-'Așrīyah, 1941.

Bakr (al), Muḥammad 'Abd al-Raḥmān. al-Sultah al-Qadà'yyah wa Shakbsìyat al-Qadā' fì al-Nižàm al-Islämì. Kairo: Madīnah Nașr, 1998.

Bukhārī (al), Abū 'Abd Allah Muḥammad b. Ismāil b. Ibrāhīm b. alMughīrah b. Bardizbah al-Ju'fì. Șạ̣ị̧ al- Bukhārì, Vol. 6. Beirut: Dār Ibn Kathīr, 1987.

\footnotetext{
${ }^{27}$ Hilaluddin Said, "Wilāyat al-Mazălim dan Pengadilan Tata Usaha Negara (PTUN) dalam Perbandingan” (Skripsi--IAIN Syarif Hidayatullah Jakarta, 2000); Azhariah Khalida, "Wilāyat al-Mazaălim dan Prospeknya dalam Pembentukan Masyarakat Madani” (Tesis--IAIN Imam Bonjol Padang, 2002).
} 


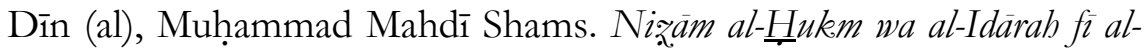
Isläm. t.t.: al-Mu'assasah al-Dawlīyah li al-Dirāsat wa al-Nashr, 1991.

Hamzah, Andi. Asas-asas Hukum Pidana. Jakarta: PT. Rineka Cipta, 1994.

'Ilyān, Shawkat. Qad̄à' al-Mazăàlim fì al-Islām. Baghdād: Matba'at alJāmi'ah, 1977.

Institute, Swedish. Fact Sheets on Sweden. Sweden, January 1972.

Kanter, EY. dan Sianturi, S.R. Asas-asas Hukum Pidana di Indonesia dan Penerapannya. Jakarta: Storia Grafika, 2002.

Khalida, Azhariah. "Wilāyat al-Mažălim dan Prospeknya dalam Pembentukan Masyarakat Madani”. Tesis--IAIN Imam Bonjol Padang, 2002.

Ma'lūf, Louis. al-Munjid $f_{\grave{\imath}}$ al-Lughah. Beirut: al-Maṭba'ah alKāthūlikìyah, t.th.

Māwardī (al), 'Alī Muhammad b. Habīb. al-A Ạkeàm al-Sultānīyah wa alWilāyàt al-Dinìyah. Beirut: Dār al-Kutub al-'Ilmīyah, t.th.

Nabhani, Taqiyuddin. Sistem Pemerintahan Islam: Doktrin, Sejarah, dan Realitas Empirik. Bangil: al-Izzah, 1996.

Nusantara, Abdul Hakim Garuda. "Mengadili Kasus-Kasus Pelanggaran Hak Asasi Manusia: Pengalaman Beberapa Negara", Makalah pada Seminar Nasional Rancangan Undang-Undang tentang Pengadilan Hak Asasi Manusia 16 Februari 2000, Jakarta: Direktorat Jenderal Hukum dan Perundang-undangan Departemen Hukum dan Perundang-undangan R.I.

Prodjodikoro, Wirjono. Asas-asas Hukum Pidana di Indonesia. Bandung: Eresco, 1989.

Said, Hilaluddin. "Wilayat al-Mazaălim dan Pengadilan Tata Usaha Negara (PTUN) dalam Perbandingan". Skripsi--IAIN Syarif Hidayatullah Jakarta, 2000.

Statute of the International Tibunal for Former Yugoslavia, Adopted 25 May 1993 as Amended 13 May 1998.

Sujata, Antonius. "Ombudsman dalam Konstitusi", Forum Keadilan, No. 27, 7 Oktober 2001.

Ṭārifì, Nāsir b. 'Āqil b. Jābir. al-Qadàa' fì 'Ahd 'Umar. Jeddah: Dār alMadānī, 1986.

Zahrah, Muhạmmad Abū. al-Jarimah wa al-'Uqūbah fì al-Fiqh al-Jinā'̀ alIslämì. Kairo: Dār al-Fikr al-'Arabī, t.th. 
Ikhwan

Zallum, Abdul al-Qadim. Sistem Pemerintahan Islam, terj. Moh. Maghfur Wachid. Bangil: al-Izzah, 2002.

Zein, Satria Effendi M. "Arbitrase dalam Syariat Islam", dalam Arbitrase Islam di Indonesia. Jakarta: Badan Arbitrase Muamalat Indonesia, 1994. 